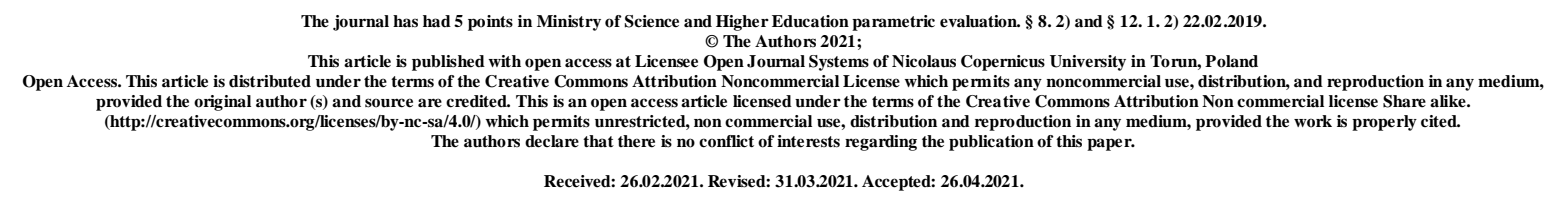

\title{
CLINICAL-ANAMNESTIC FEATURES OF MENTAL EXHAUSTION IN MEDICAL
} UNIVERSITY STUDENTS

\author{
S. O. Yefimenko
}

\section{Zaporizhzhia State Medical University, Ukraine}

Yefimenko Serhii Olehovych - head teacher of Department of Physical Rehabilitation, Sports Medicine, Physical Education and Health, Zaporizhzhia State Medical University. Address: Ukraine, 69035, Zaporizhzhia, Mayakovsky Avenue, 26. Tel.: +38(061) 233-96-66. E-mail: sergmayohn@gmail.com

\section{Abstract}

In order to assess the prevalence and anamnestic features of mental exhaustion in medical university students, a clinical-anamnestic, clinical-psychopathological and psychodiagnostic study of 770 junior medical students was conducted. The results of the study revealed the prevalence of mental exhaustion among students at 54\%; The most sensitive to the development of these conditions are students of the 3rd year of medical university, regardless of the specialty of study (medicine, dentistry, physical therapy, etc.), age, gender and living conditions, this may be due to the high intensity of the learning process during this period of study. The influence of mental exhaustion on the level of academic success of students is estimated - it leads to a decrease in the subjective assessment of students' academic performance in the form of devaluation of their own success.

Key words: mental exhaustion; students; maladaptation; academic success.

Background. The period of study at a university is filled with a set of maladaptive factors, which differ in their structure and intensity depending on the specialty that the future 
specialist receives. For students of medical universities states of mental exhaustion are more typical - complexes of psychopathological symptoms of subclinical level, characterized by exhaustion of mental functions and which, as a result, lead to persistent psychosocial maladaptation. Recent studies have found that the widest range of maladaptive factors is observed in the first years of study: change of life stereotype (change of place of living and studying, new environment), difficulties in learning (much more workload than in school) and a new stereotype of interpersonal relationships (with teachers) - lead to states of information and emotional distress, significant mental and physical exhaustion. It is important to identify the patterns of occurrence of these conditions among future doctors.

The objective: to establish the prevalence and anamnestic features of mental exhaustion in medical university students.

Materials and methods. In compliance with the principles of bioethics and with voluntary informed consent, 770 students of Zaporizhzhia State Medical University (Zaporizhzhia, Ukraine) were examined during the session; these students studied at various courses and faculties of the university, among them 324 students were selected for further clinical-anamnestic, clinical-psychopathological and psychodiagnostic research.

The total sample of the research contingent was formed by 92 first-year students (28.4\%), 97 second-year students (29.94\%), 116 third-year students (35.8\%) and 19 senior students (5.86\%). To identify the state of mental exhaustion were used: Questionnaire of emotional burnout (K. Maslach, S. Jackson in the adaptation) and Questionnaire of SAN (health, activity, mood).

Results. With the help of the conducted clinical-psychopathological and psychodiagnostic studies, the prevalence of mental exhaustion states among students of a medical university was established. Thus, it was found that 175 students $(54.0 \%$ of respondents) demonstrate signs of mental exhaustion, they formed the research group (RG), the last 149 students (46.0\%) did not show diagnostically significant signs of mental exhaustion and formed a comparison group (CG).By comparing the prevalence of anamnestic correlates in both groups, we analyzed their significance in the context of the onset of states of mental exhaustion. The anamnestic criteria were structured by descent into two groups: university-related and unrelated. Table 1 shows a comparison of anamnestic criteria unrelated to studding in the RG and CG. 
Table 1

Comparative analysis of the representation of the unrelated to training anamnestic correlates of students of the RG and CG

\begin{tabular}{|c|c|c|c|c|}
\hline Criteria group & Criterion & $\begin{array}{c}\text { RG } \\
\text { (175 students) }\end{array}$ & $\begin{array}{c}\text { CG } \\
\text { (149 students) }\end{array}$ & $\begin{array}{c}\chi^{2-} \\
\text { distribution }\end{array}$ \\
\hline \multirow[t]{5}{*}{ Age (1 years) } & $16-17$ & $26(14.9 \%)$ & $33(22.1 \%)$ & 0.09 \\
\hline & $18-19$ & $112(64.0 \%)$ & $81(54.4 \%)$ & 0.078 \\
\hline & $20-21$ & $30(17.1 \%)$ & $28(18.8 \%)$ & 0.7 \\
\hline & $22-23$ & $7(4.0 \%)$ & $5(3.4 \%)$ & 0.76 \\
\hline & $\geq 24$ & 0 & $2(1.3 \%)$ & 0.124 \\
\hline \multirow[t]{2}{*}{ Gender } & male & $41(23.4 \%)$ & $43(28.9 \%)$ & \multirow{2}{*}{0.266} \\
\hline & female & $134(76.6 \%)$ & $106(71.1 \%)$ & \\
\hline \multirow{4}{*}{$\begin{array}{l}\text { Working outside of } \\
\text { studding hours } \\
\text { (hours per week) }\end{array}$} & 0 (doesn`t work) & $139(79.4 \%)$ & $122(81.9 \%)$ & 0.579 \\
\hline & $1-20$ & $22(12.6 \%)$ & $13(8.7 \%)$ & 0.266 \\
\hline & $21-40$ & $10(5.7 \%)$ & $13(8.7 \%)$ & 0.293 \\
\hline & $41-60$ & $3(1.7 \%)$ & $4(2.7 \%)$ & 0.549 \\
\hline \multirow[t]{4}{*}{ Living conditions } & living with family & $52(29.7 \%)$ & $47(31.5 \%)$ & 0.722 \\
\hline & $\begin{array}{l}\text { living in a university } \\
\text { dormitory }\end{array}$ & $74(42.3 \%)$ & $59(39.6 \%)$ & 0.624 \\
\hline & independent living & $22(12.6 \%)$ & $25(16.8 \%)$ & 0.284 \\
\hline & $\begin{array}{l}\text { having a romantic } \\
\text { relationship }\end{array}$ & $82(46.9 \%)$ & $67(45.0 \%)$ & 0.734 \\
\hline \multirow[t]{6}{*}{ Creed } & none (atheism) & $55(31.4 \%)$ & $35(23.5 \%)$ & 0.112 \\
\hline & Christianity & $110(62.9 \%)$ & $103(69.1 \%)$ & 0.236 \\
\hline & Catholic & $4(2.3 \%)$ & $4(2.7 \%)$ & 0.818 \\
\hline & Islam & $2(1.1 \%)$ & $3(2.0 \%)$ & 0.526 \\
\hline & other & $4(2.3 \%)$ & $4(2.7 \%)$ & 0.818 \\
\hline & $\begin{array}{l}\text { active participation } \\
\text { in the activities of } \\
\text { the religious } \\
\text { community }\end{array}$ & $13(7.4 \%)$ & $10(6.7 \%)$ & 0.803 \\
\hline
\end{tabular}


The obtained data indicate the absence of statistically significant differences between the comparison groups for all unrelated to university studies anamnestic criteria, which may indicate the structural homogeneity of RG and CG and increase the significance of differences that will be identified between these groups in the future.

The presence of work activity outside the classroom and its intensity don't in any way $(\mathrm{p}=0.579)$ affect the occurrence of states of mental exhaustion in junior students of a medical university. Despite the high intensity of the educational process, the accompanying work activity does not worsen the mental state of students.

The lack of dependence of the states of mental exhaustion in the studied contingent of students on living conditions $(\mathrm{p}>0.05)$ does not correspond to some scientific studies that were devoted to this topic, this can be explained by the peculiarities of a particular university (the respondents generally assessed their living conditions as satisfactory and high) and the fact that when filling out anamnestic questionnaires, the students were examined were on distance learning due to quarantine restrictions.

Noteworthy is the lack of dependence between states of mental exhaustion and a group of religious factors, such as a specific religion ( $p>0.05)$ or active participation in the activities of a religious community $(\mathrm{p}=0.803)$. This may indicate the absence of a pattern of coping with stress in the studied contingent of students through the use of religious beliefs and practices.

Table 2 compares the anamnestic criteria associated with study in RG and CG.

According to the obtained data, a statistically significant difference $(\mathrm{p}=0.004)$ was revealed between the comparison groups according to the criterion of the course of study, so it was found that the share of third-year students in the RG significantly prevails over the CG 75 students $(42.9 \%)$ compared with 41 students $(27.5 \%)$. This can be explained by the high level of intensity of the educational process among all the studied courses, which is associated with the preparation of the majority of students for passing state exams at the end of the third year.

There was no influence on the occurrence of a state of mental exhaustion in the surveyed contingent of students and the specialty in which they studied at the medical university - no differences were found between the prevalence rates of the studied mental phenomena among students of medical $(\mathrm{p}=0.941)$, dental $(\mathrm{p}=0.922)$, pharmaceutical $(p=0.496)$ and other faculties. 
Comparative analysis of the representation of anamnestic correlates in students of RG and CG related to learning

\begin{tabular}{|c|c|c|c|c|}
\hline Criteria group & Criterion & $\begin{array}{c}\text { RG } \\
\text { (175 students) }\end{array}$ & $\begin{array}{c}\text { CG } \\
\text { (149 students) }\end{array}$ & $\begin{array}{c}\chi^{2-} \\
\text { distribution }\end{array}$ \\
\hline \multirow[t]{4}{*}{ Year of study } & $1^{\text {st }}$ & $44(25.1 \%)$ & $48(32.2 \%)$ & 0,159 \\
\hline & $2^{\text {nd }}$ & $48(27.4 \%)$ & $49(32.9 \%)$ & 0.285 \\
\hline & $3^{\text {rd }}$ & $75(42.9 \%)$ & $41(27.5 \%)$ & 0.004 \\
\hline & $4-6^{\text {th }}$ & $8(4.6 \%)$ & $11(7.4 \%)$ & 0.283 \\
\hline \multirow[t]{5}{*}{ Specialty } & Medicine & $105(60.0 \%)$ & $90(60.4 \%)$ & 0.941 \\
\hline & Pharmacy & $32(18.3 \%)$ & $23(15.4 \%)$ & 0.496 \\
\hline & $\begin{array}{l}\text { Laboratory } \\
\text { diagnostics }\end{array}$ & $10(5.7 \%)$ & $7(4.7 \%)$ & 0.683 \\
\hline & Dentistry & $24(13.7 \%)$ & $21(14.1 \%)$ & 0.922 \\
\hline & $\begin{array}{l}\text { Physical therapy } \\
\text { and occupational } \\
\text { therapy }\end{array}$ & $4(2.3 \%)$ & $8(5.4 \%)$ & 0.143 \\
\hline \multirow[t]{3}{*}{ Academic success } & $\begin{array}{l}\text { High average score } \\
(« \mathrm{~B} » \text { and above })\end{array}$ & $107(61.1 \%)$ & $98(65.8 \%)$ & 0.389 \\
\hline & $\begin{array}{l}\text { Skipping classes } \\
\text { for disrespectful } \\
\text { reasons no more } \\
\text { than once a month }\end{array}$ & $143(81.7 \%)$ & $134(89.9 \%)$ & 0.036 \\
\hline & $\begin{array}{l}\text { High subjective } \\
\text { assessment of one's } \\
\text { own academic } \\
\text { performance }\end{array}$ & $17(9.7 \%)$ & $27(18.1 \%)$ & 0,028 \\
\hline
\end{tabular}

highlighted in gray

It was also found that RG students were more likely to miss classes for no valid reason $(\mathrm{p}=0.036)$ and provided a lower subjective assessment of their own academic performance $(\mathrm{p}=0.028)$ than $\mathrm{CG}$ students, despite the fact that there were no statistically significant differences in the mean score between the groups $(\mathrm{p}=0.389)$. The obtained results may indicate the devaluation of their own success by students, as one of the manifestations of mental exhaustion.

\section{Conclusions}

1. States of mental exhaustion are quite common among junior-year students of a medical university (they reach 54.0\%), but third-year students are the most vulnerable in this context, which may be due to the high intensity of the educational process during this period. 
2. The onset of states of mental exhaustion in medical university students does not depend on gender, work activity, living conditions or a specific medical specialty.

3. The studied conditions lead to a decrease in the subjective assessment of the academic performance of students in the form of a devaluation of their own success.

The prospect for further research is to analyze the relationship between the occurrence of states of mental exhaustion and the characterological characteristics of students of a medical university.

\section{References}

1. Vasileva Yu. S., Kolesnikova E. I., Hafiyatullina E. R. (2018)Individualnyie I lichnostnyie factory iformirovaniya bilingvizma studentov vuza [Individual and personal factors in the formation of bilingualism of university students]. Pedagogika I Prosveschenie, 2(2), 8-21. https://doi.org/10.7256/2454-0676.2018.2.26290.

2. Baboshkina L. S., Gaydarova D. S. (2019) Situativnaya trevozhnost I immunnayadez adaptatsiya u studentov meditsinskih I nemeditsinskih vuzov [Situational anxiety and immune maladjustment in students of medical and non-medical universities].Byulleten meditsinskih internet-konferentsiy, 9(1), 33-53.

3. Tyuryapina I. V. (2016) Osobennosti psihoemotsionalnogo sostoyaniya $\mathrm{u}$ studentov s razlichnyimi aktsentuatsiyami lichnosti v period adaptatsii k vuzu [Peculiarities of the psychoemotional state of students with different personality accentuations during the period of adaptation to the university]. Mir nauki, kulturyi, obrazovaniya, 1(56),246-250.

4. Dyrbye L. N., Massie F. S., Eacker A. et al. (2010) Relationship Between Burnout and Professional Conduct and Attitudes Among US Medical Students. JAMA, 304(11), 1173-1180. doi:10.1001/jama.2010.1318.

5. Colbert-Getz, J. M., Fleishman, C., Jung, J., \& Shilkofski, N. (2013). How Do Gender and Anxiety Affect Students' Self-Assessment and Actual Performance on a HighStakes Clinical Skills Examination? Academic Medicine, 88(1), 44-48. https://doi.org/10.1097/acm.0b013e318276bcc4

6. Dyrbye, L. N., Thomas, M. R., Harper, W., Massie, F. S., Power, D. V., Eacker, A., Szydlo, D. W., Novotny, P. J., Sloan, J. A., \& Shanafelt, T. D. (2009). The learning environment and medical student burnout: a multicentre study. Medical Education, 43(3), 274-282. https://doi.org/10.1111/j.1365-2923.2008.03282.x 
7. Pereira, M. A. D., Barbosa, M. A., de Rezende, J. C., \& Damiano, R. F. (2015). Medical student stress: An elective course as a possibility of help. BMC Research Notes, 8(1).https://doi.org/10.1186/s13104-015-1399-y 